\title{
Measuring International Trade Policy: A Primer on Trade Restrictiveness Indices
}

\author{
Cletus C. Coughlin
}

\begin{abstract}
Measuring the overall restrictiveness of a country's international trade policies is important and, in fact, essential for estimating the effects of trade policies and for negotiations to reduce trade barriers. A good measure is also difficult to produce: Trade restrictiveness indices are constructed by combining the actual structure of trade restrictions, which is generally quite different across goods, into a single number. Under certain assumptions, this single number is the uniform tariff that would produce the same trade restrictiveness as the actual differentiated structure of restrictions. In this paper, the economic intuition underlying the construction of these indices is presented and estimates of these indices and the resulting insights are summarized. (JEL F00, F13, C43)
\end{abstract}

Federal Reserve Bank of St. Louis Review, September/October 2010, 92(5), pp. 381-94.

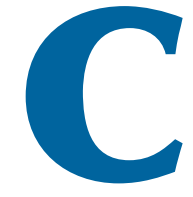

ountries commonly use tariffs and other barriers to deter the importation of foreign-produced goods. Such trade policies affect economic activity and economic well-being not only in the country enacting these policies but in other countries as well. A fundamental question when assessing these policies is how restrictive overall a country's trade policies actually are. Ideally, one would like to have a measure that provides insights concerning not only how a country's restrictiveness has changed over time, but also how it compares with its trading partners'.

The present paper focuses on the measurement of trade restrictiveness. Particular attention is given to measures that are termed trade restrictiveness indices. Such indices are produced by combining actual trade restrictions, which are generally quite different across goods, into a single number. This single number is the uniform tariff factor equivalent that would produce the same trade restrictiveness as the actual structure of restrictions. In the case of a specific index discussed later, this tariff, if applied to every imported good, would generate the same result for a nation's economic wellbeing as the actual set of trade barriers. ${ }^{1}$ Trade restrictiveness indices are valuable for many purposes, such as assessing the impact of trade policy on economic and social outcomes and providing useful information for trade negotiations. Because of the importance of trade restrictiveness indices, an elementary introduction to these indices should be of value for researchers, policymakers, and students.

Unlike trade restrictiveness indices, more common measures of trade restrictiveness can be characterized as ad hoc and, thus, flawed. Therefore, studies using these less-rigorous measures of the impacts of trade policy on economic welfare and performance should be viewed with skepticism.

Beginning with the pioneering efforts of James Anderson and Peter Neary in the early 1990s,

\footnotetext{
1 As discussed later, trade restrictiveness indices can also be constructed relative to other measures of economic activity, such as the volume of imports.
}

Cletus C. Coughlin is a vice president and deputy director of research at the Federal Reserve Bank of St. Louis. The author thanks Mariana Spatareanu, Vlad Manole, and Silvio Contessi for comments on an earlier draft. Lesli Ott provided valuable research assistance.

(C) 2010, The Federal Reserve Bank of St. Louis. The views expressed in this article are those of the author(s) and do not necessarily reflect the views of the Federal Reserve System, the Board of Governors, or the regional Federal Reserve Banks. Articles may be reprinted, reproduced, published, distributed, displayed, and transmitted in their entirety if copyright notice, author name(s), and full citation are included. Abstracts, synopses, and other derivative works may be made only with prior written permission of the Federal Reserve Bank of St. Louis. 
much progress on the measurement of trade restrictiveness indices has occurred, including developments in economic theory and estimation that will be discussed here. ${ }^{2}$ The theoretical advances use general equilibrium analysis, an approach that examines all markets in an economy at the same time. Thus, changes in one market can affect many other markets, and the determination of all equilibrium prices and quantities of all goods and services occurs simultaneously. Without question, such an analysis provides strong foundations for trade restrictiveness indices. However, to increase reader understanding of the key points in this paper, the following discussion of trade restrictiveness indices relies on partial equilibrium analysis, an approach that considers only part of an economy, such as the market for a specific good.

\section{MEASURES OF TRADE RESTRICTIVENESS: CONSTRUCT WITH CARE ${ }^{3}$}

To show how difficult it is to measure a country's trade restrictiveness, I examine a number of situations that illustrate problems with existing measures and provide the foundation for understanding the advances associated with trade restrictiveness indices.

\section{A Very Simple Case}

The measurement of trade restrictiveness is straightforward when there is only one imported good and a tariff is applied. Figure 1 illustrates this simple case. The import demand for this good is represented by $\mathrm{D}^{\mathrm{M}}{ }^{4}$ The price in world markets for this good is $\mathrm{P}_{\mathrm{W}}$, which is the price

2 See Anderson and Neary (1992, 1994, 1996, 2003, and 2007) and Anderson (1998). A compilation of their work is presented in Anderson and Neary (2005).

3 A more thorough discussion of the ideas in this section can be found in Anderson and Neary (2005).

4 To be consistent with the underlying theory, this demand curve is a compensated net import demand curve. A compensated demand function, also known as a Hicksian demand function, reflects demand for a bundle of goods that minimizes expenditure while providing a fixed level of utility. The curve is characterized as "net" faced by domestic producers and consumers prior to the imposition of the tariff. Thus, the quantity of imports is $\mathrm{M}_{\mathrm{W}}$.

Now assume a tariff is imposed that raises the price faced by domestic producers and consumers to $\mathrm{P}_{\mathrm{T}}$. As a result of the higher price, imports would decrease to $\mathrm{M}_{\mathrm{T}}$. The deadweight loss caused by the tariff is represented by the triangle ABC. ${ }^{5}$ The restrictiveness of this tariff is simply the height of the tariff, which is the difference between $\mathrm{P}_{T}$ and $\mathrm{P}_{\mathrm{W}}$. Trade restrictiveness increases the larger the difference between the domestic price and the price in world markets. This simplicity vanishes, however, when assessing trade restrictiveness with two or more goods and tariffs.

\section{Problems with Existing Measures}

Let's begin with a case of two goods that are subjected to different tariffs. One approach could be to construct a measure of trade restrictiveness by computing the simple (i.e., unweighted) average of the two tariff rates. An obvious problem here is that all goods are treated identically. Intuitively, the goods should be weighted in terms of their importance. ${ }^{6}$ One common weighting approach is to use actual import volumes as weights. Unfortunately, such an approach is flawed.

When a uniform tariff is imposed on all the goods in question, the calculation of an average tariff weighted by import volumes generates a reasonable index: that a higher average tariff accu-

because it is derived from the country's supply and demand curves for the good. Using prices less than the price associated with the intersection of the supply and demand curves, the import demand curve is the difference between quantity demanded and quantity supplied.

5 The deadweight loss stems from the distortion of consumption and production decisions resulting from the wedge between the domestic price and the world price caused by the tariff. The fact that domestic consumers and producers face a price that exceeds the world price leads to inefficiencies associated with consumption as well as production. First, some would-be purchasers whose marginal benefits would exceed the world price are not buyingand, therefore, not consuming - the good because of the additional costs imposed by the tariff. Second, some domestic producers whose marginal costs exceed the world price are producing the good.

6 As pointed out by Mariana Spatareanu in personal correspondence, the simple average can be easily manipulated. To reduce its average tariff rate, a country may simply create a large number of categories of goods with zero or very low tariffs. 


\section{Figure 1}

\section{One Imported Good Subject to Tariff}

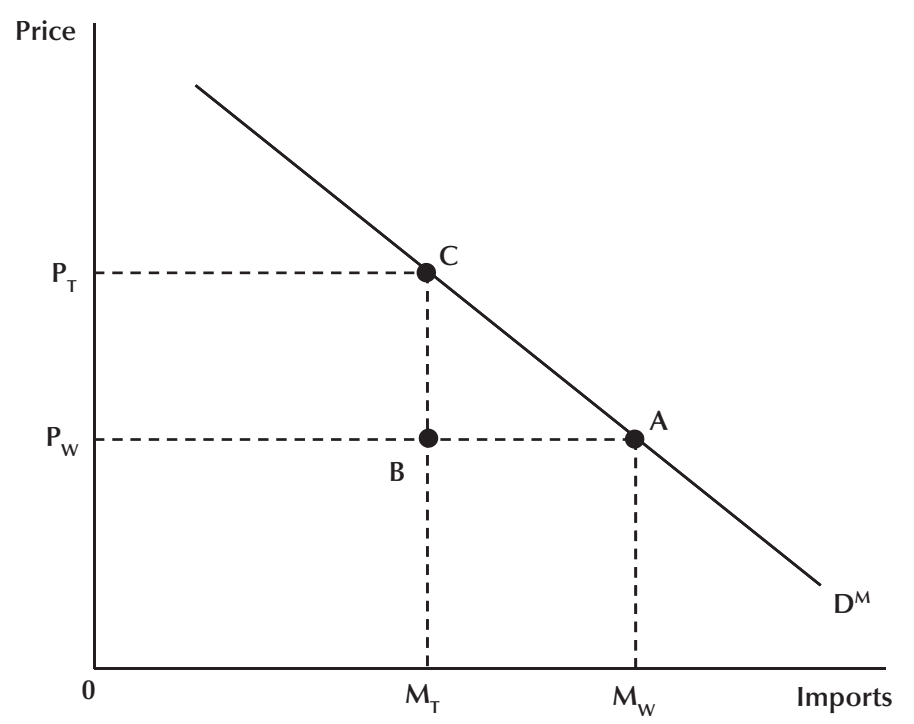

rately indicates a more restrictive policy. However, with a differentiated tariff structure, goods subject to high tariffs will tend to receive lower weight than goods subject to low tariffs. The reason is that the price of a good with a high tariff will tend to rise relative to a good with a low tariff, so consumers will tend to substitute the good with the low tariff for the one with the high tariff. As a result, in the calculation of the import-weighted average tariff, goods with high tariffs will tend to receive less weight than goods with low tariffs. This would tend to reduce the value of the index, which is precisely the opposite of what seems reasonable. ${ }^{7}$

Using Figures 2 and 3, let's examine more closely the usefulness of an average tariff weighted by import volumes. Identical to the preceding discussion, we use the case of two goods with different tariffs. In Figure 2, the left half of the diagram contains information on good M1 and the right half on good M2. Similar to Figure 1, the

7 In an extreme case, a restriction could be so high that no imports occur, so that the restriction would receive no weight in the calculation. demand for $\mathrm{M} 1$ is represented by $\mathrm{D}^{\mathrm{M} 1}$ and the demand for $\mathrm{M} 2$ is represented by $\mathrm{D}^{\mathrm{M} 2}$. Note that the quantity of M1 increases with leftward movements along the horizontal axis and that the quantity of M2 increases with rightward movements along the horizontal axis. To simplify, but without losing any generality, the price in world markets for both goods is assumed to be $\mathrm{P}_{\mathrm{W}}$. Prior to the imposition of a tariff, $\mathrm{P}_{\mathrm{W}}$ is the price faced by domestic producers and consumers for both goods. Thus, the quantity of imports of $\mathrm{M} 1$ is $\mathrm{M} 1_{\mathrm{W}}$ and of M2 is $\mathrm{M} 2{ }_{\mathrm{W}}$.

Now assume tariffs are imposed such that a lower tariff rate is imposed on the good with the higher price elasticity of import demand (i.e., M1) than is imposed on the good with the lower price elasticity of import demand (i.e., M2). ${ }^{8}$ In other words, the tariff rate imposed on $\mathrm{M} 1$ is $\left(\mathrm{P}_{1}-\mathrm{P}_{\mathrm{W}}\right) / \mathrm{P}_{\mathrm{W}}$, while the tariff rate imposed on M2 is $\left(\mathrm{P}_{2}-\mathrm{P}_{\mathrm{W}}\right) / \mathrm{P}_{\mathrm{W}}$. Thus, as drawn, there is a negative

8 The price elasticity of demand is the percentage change in quantity demanded divided by the percentage change in price. This elasticity is generally expressed as an absolute value, a convention that we follow in our discussion. Consequently, larger values for the price elasticity of demand are associated with flatter demand curves. 
Figure 2

Tariff Rates and Import Demand Elasticities: Negative Correlation

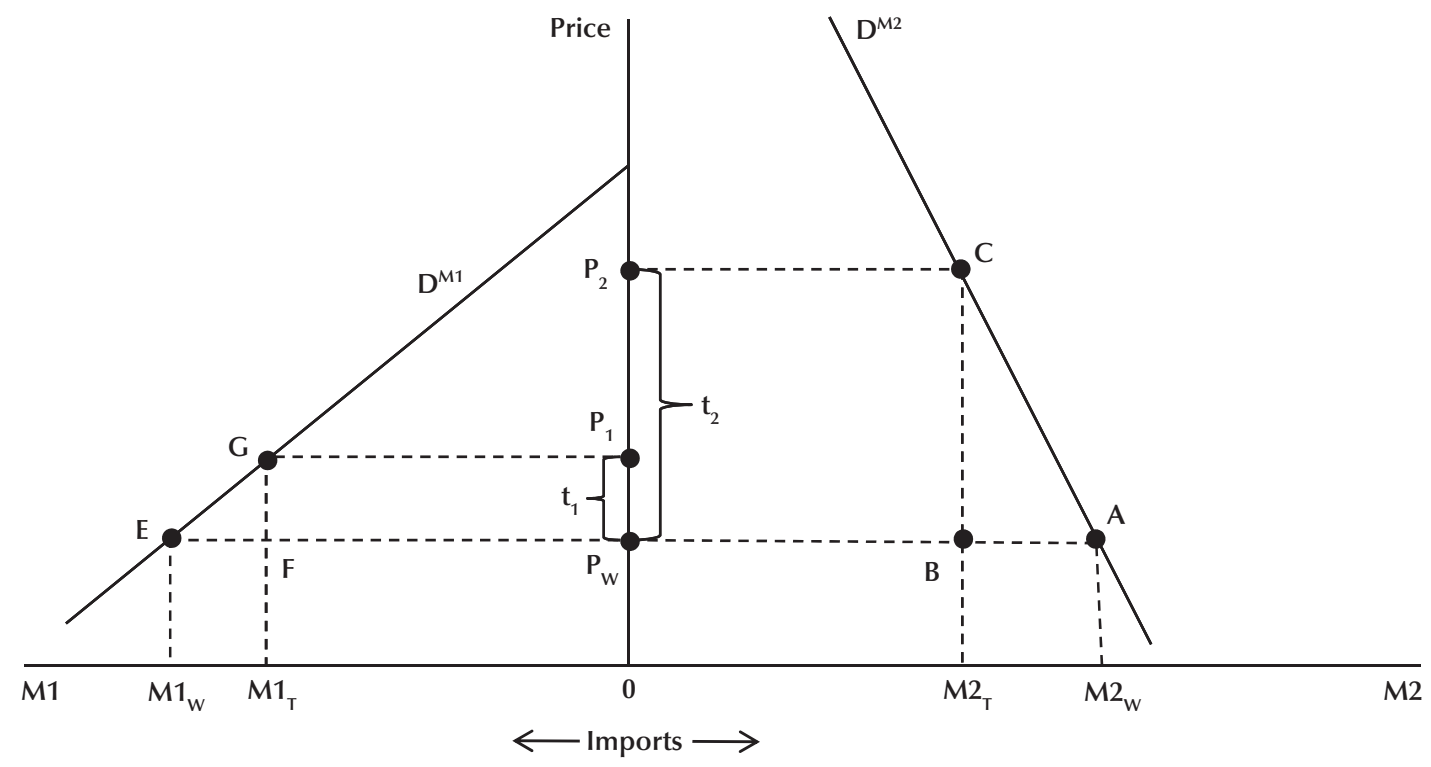

Figure 3

Tariff Rates and Import Demand Elasticities: Positive Correlation

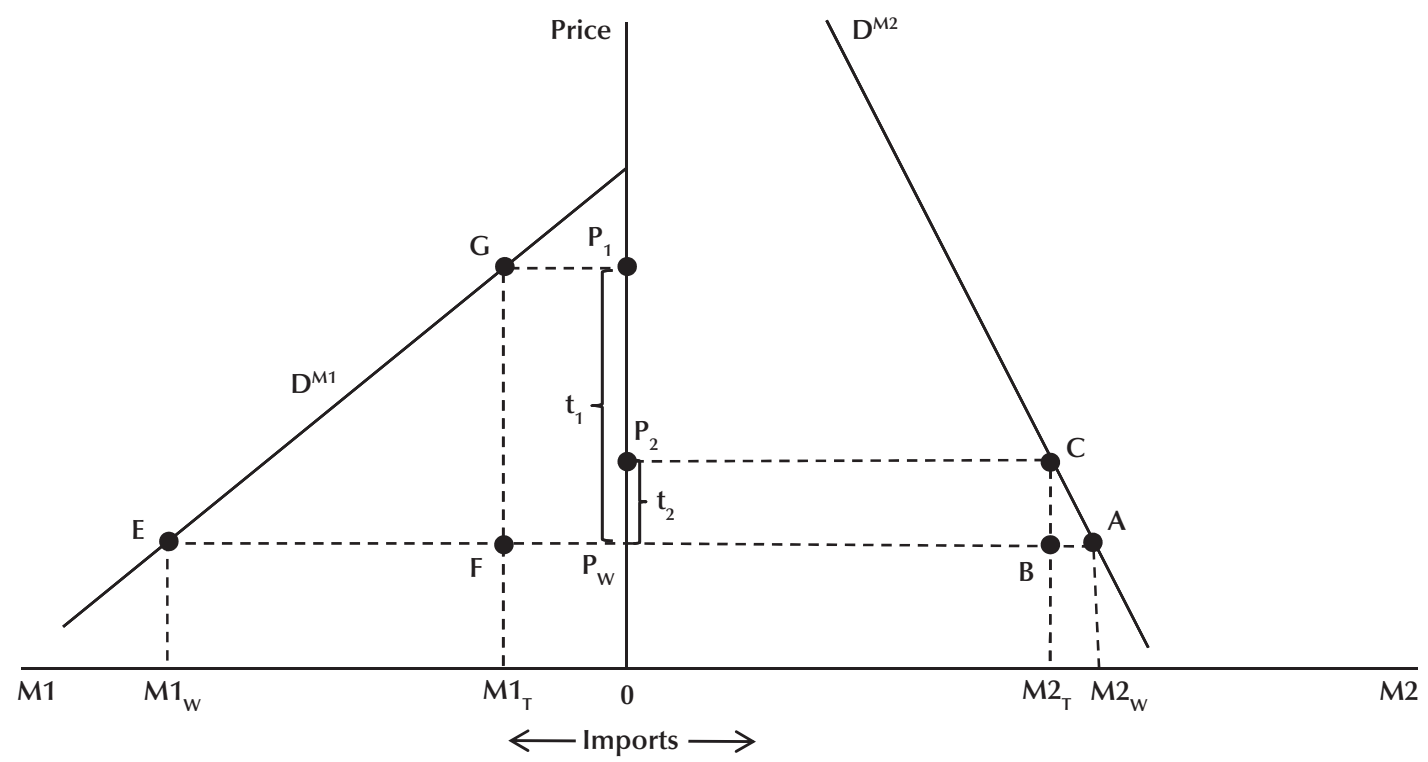


correlation between the tariff rate and the elasticity. In this case the tariff on M1 causes the price for domestic consumers and producers to increase to $\mathrm{P}_{1}$ and the tariff on $\mathrm{M} 2$ causes the price to increase to $\mathrm{P}_{2}$. As a result, imports would decrease to $\mathrm{M} 1_{\mathrm{T}}$ and $\mathrm{M} 2_{\mathrm{T}}$, respectively.

Using Figure 2, let $t_{1}$ be the specific (i.e., dollar amount) tariff for $\mathrm{M} 1$ and $\mathrm{t}_{2}$ be the specific tariff for M2. Then, the trade-weighted average tariff rate, $\mathrm{t}_{\mathrm{w}}$, is: $\mathrm{t}_{\mathrm{w}}=\left(\mathrm{t}_{1} \mathrm{M} 1_{\mathrm{T}}+\mathrm{t}_{2} \mathrm{M} 2_{\mathrm{T}}\right) /\left(\mathrm{P}_{\mathrm{W}} \mathrm{M} 1_{\mathrm{T}}+\mathrm{P}_{\mathrm{W}} \mathrm{M} 2_{\mathrm{T}}\right){ }^{9}$ The numerator is the value of tariff revenue, while the denominator is the value of imports using world prices, which were assumed to be identical for the two goods. ${ }^{10}$

Now let's examine Figure 3. Once again, the left half contains information on good M1 and the right half on good M2, where the demand for $\mathrm{M} 1$ is represented by $\mathrm{D}^{\mathrm{M} 1}$ and the demand for M2 by $\mathrm{D}^{\mathrm{M} 2}$. The price in world markets for both goods is assumed to be $\mathrm{P}_{\mathrm{W}}$. Prior to the imposition of a tariff, $\mathrm{P}_{\mathrm{W}}$ is the price faced by domestic producers and consumers for both goods. Thus, the quantity of imports of M1 is $\mathrm{M}_{\mathrm{W}}$ and of $\mathrm{M} 2$ is $\mathrm{M} 2_{\mathrm{W}}$. Now assume tariffs are imposed such that a higher tariff rate is imposed on the good with the higher price elasticity of import demand (i.e., M1) than on the good with the lower price elasticity of import demand (i.e., M2). The tariff rate imposed on M1 is $\left(\mathrm{P}_{1}-\mathrm{P}_{\mathrm{W}}\right) / \mathrm{P}_{\mathrm{W}}$, while the tariff rate imposed on M2 is $\left(\mathrm{P}_{2}-\mathrm{P}_{\mathrm{W}}\right) / \mathrm{P}_{\mathrm{W}}$. Thus, there is a positive correlation between the tariff rate and the elasticity. In this case, the tariff on M1 causes the price for domestic consumers and producers to increase to $\mathrm{P}_{1}$ and the tariff on $\mathrm{M} 2$ causes the price to increase to $\mathrm{P}_{2}$. As a result, imports would decrease to $\mathrm{M} 1_{\mathrm{T}}$ and $\mathrm{M} 2_{\mathrm{T}}$, respectively.

In Figure 3, compared with Figure 2, imports of M1 are lower and imports of M2 are higher. Thus, for the calculation of the trade-weighted average tariff rate, $\mathrm{M} 1$ will receive less weight

\footnotetext{
9 Often, this tariff rate is multiplied by 100 to express the rate in percentage terms.

10 The example uses two imported goods. Sometimes the calculation is made using only goods with tariffs. If all other goods can be imported without any restrictions, the calculation will overstate the degree of restrictiveness. As we shall discuss later, additional complications arise when imported goods are subjected to trade barriers that yield no tariff revenue.
}

and M2 will receive more weight. Moreover, the absolute decrease in the quantity of imports of M1 exceeds the increase in the quantity of imports of M2. Recall also that the tariff rate on M1 (M2) in Figure 3 is the tariff rate on M2 (M1) in Figure 2. Thus, M1 (M2) is subject to a higher (lower) tariff rate in Figure 3 than in Figure 2. Consequently, the trade-weighted average tariff rate in Figure 3 must be less than in Figure 2. That trade is more restricted in Figure 3 than in Figure 2 suggests that the trade-weighted average tariff rate is a flawed measure. ${ }^{11}$

Another way to show that the tariffs in Figure 3 are more restrictive than those in Figure 2 is to examine the deadweight losses. The deadweight losses in Figure 3 exceed those in Figure 2. These losses are determined by the sizes of the triangles formed by EFG for good M1 and by ABC for good M2. By visual inspection and by mathematics as well, the sum of the areas of EFG and ABC is larger in Figure 3 than in Figure 2. The economic reason for this result hinges on the correlation between tariff rates and import demand elasticities. For a specific good, the higher (lower) the tariff, the larger (smaller) the deadweight loss. In comparing Figure 2 with Figure 3, when the higher tariff is switched to the good that is relatively elastic and the lower tariff is switched to the good that is relatively inelastic, then the increase in the deadweight loss associated with M1 exceeds the decrease in the deadweight loss for M2. Thus, from the perspective of national well-being, trade restrictiveness is more pronounced for the situation in Figure 3 than in Figure 2.

\section{A Better Way}

One suggestion for improving the calculation of the import-weighted average tariff rate is to use the import volumes that would result under

\footnotetext{
${ }^{11}$ Another common measure of trade restrictiveness is the import weighted coefficient of variation of tariffs, which is the standard deviation of tariff rates divided by the trade-weighted average tariff rate. The reasoning is that if two tariff schedules generate identical import-weighted tariff rates, then the schedule with less variance and, hence, a smaller standard deviation is preferred because of relatively less distortion of relative prices. However, this index still relies on the calculation of the import-weighted average tariff rate. Most importantly, it may be unreliable because it is not derived directly from economic theory.
} 


\section{Figure 4}

\section{Trade Restrictiveness Index: Tariff Rates and Import Demand Elasticities Negatively Correlated}

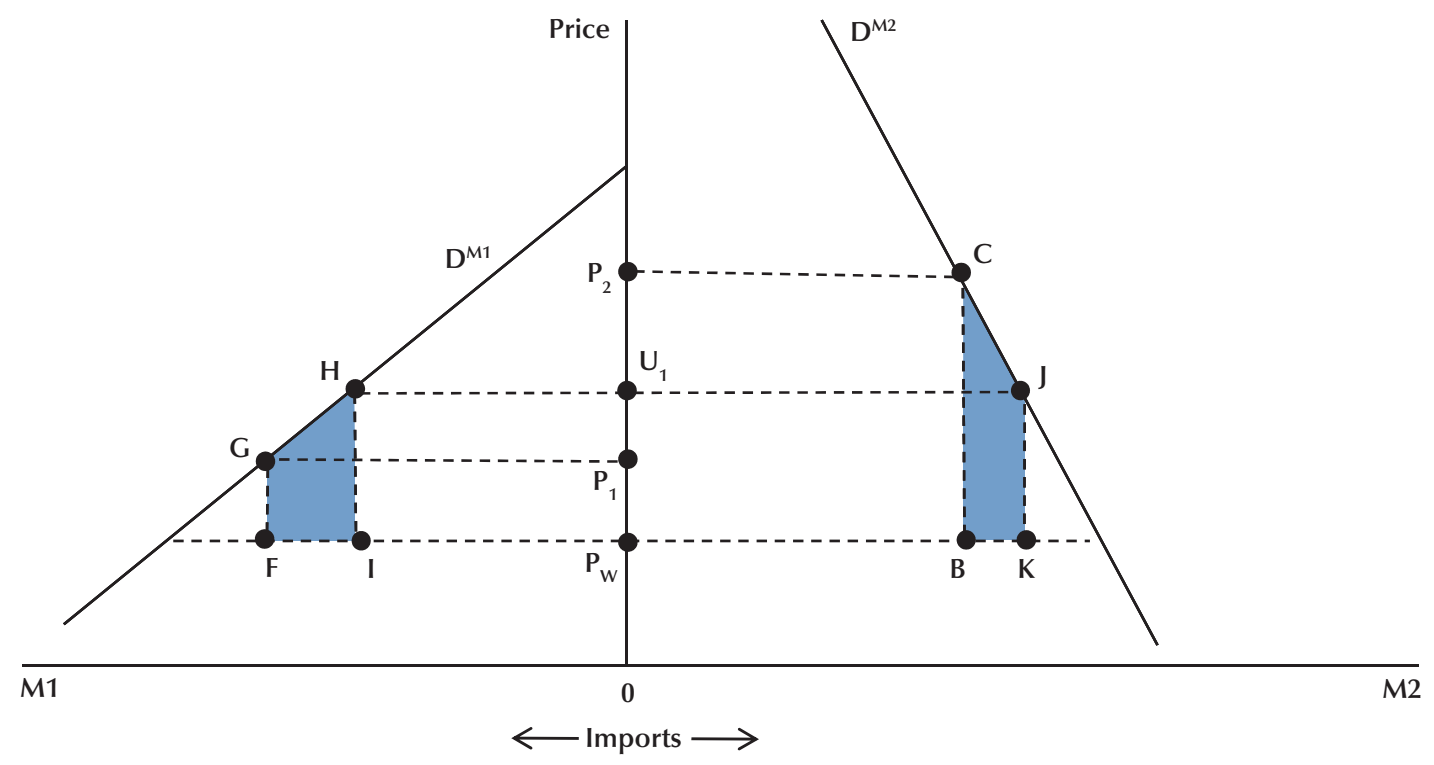

free trade to weight tariff rates rather than using the actual imports that result under current trade policy. One attractive feature of such an index is that it necessarily increases when any specific tariff rate is increased. However, because the actual trade flows under free trade are not directly observable, the trade flows and the resulting trade weights must be estimated. It turns out that the information required to estimate free-trade flows is the same as that necessary to estimate "true" indices, which are superior. We now illustrate how to construct an index that is connected to a true index, one based on the welfare or utility impacts of trade policy.

Figure 4 uses the same demand curves, prices, and tariff rates as in Figure 2. Recall that the tariff rates and the import demand elasticities are selected to be negatively correlated. The specific tariff on good M1 is $\mathrm{P}_{1}-\mathrm{P}_{\mathrm{W}}$ and on good M2 is $\mathrm{P}_{2}-\mathrm{P}_{\mathrm{W}}$. To find the uniform tariff, one must, without changing national well-being, increase the tariff on the good with the lower tariff and decrease the tariff on the good with the higher tariff until the two tariffs are equal. In the present case, the tariff associated with $\mathrm{U}_{1}$ meets this requirement. When the specific tariff on M1 increases from $\mathrm{P}_{1}-\mathrm{P}_{\mathrm{W}}$ to $\mathrm{U}_{1}-\mathrm{P}_{\mathrm{W}}$, the decline in welfare (due to the higher price and reduced imports) is represented by the area FGHI. At the same time, when the specific tariff on $\mathrm{M} 2$ decreases from $\mathrm{P}_{2}-\mathrm{P}_{\mathrm{W}}$ to $\mathrm{U}_{1}-\mathrm{P}_{\mathrm{W}}$, the increase in welfare (due to the lower price and increased imports) is represented by the area BCJK. Thus, the specific tariff, $\mathrm{U}_{1}-\mathrm{P}_{\mathrm{W}}$, is chosen so that the area FGHI equals the area BCJK. The trade restrictiveness index is simply $\left(\mathrm{U}_{1}-\mathrm{P}_{\mathrm{W}}\right) / \mathrm{P}_{\mathrm{W}}$.

Next, Figure 5 uses the same demand curves, prices, and tariff rates as in Figure 3. Recall that the tariff rates and the import demand elasticities are selected to be positively correlated. The specific tariff on good M1 is $\mathrm{P}_{1}-\mathrm{P}_{\mathrm{W}}$ and on good M2 is $\mathrm{P}_{2}-\mathrm{P}_{\mathrm{W}}$. As noted above, to find the uniform tariff, without changing national well-being, one must increase the tariff on the good with the lower tariff and decrease the tariff on the good with the higher tariff until the two tariffs are equal. In the present case, the tariff associated with $\mathrm{U}_{2}$ meets 


\section{Figure 5}

\section{Trade Restrictiveness Index: Tariff Rates and Import Demand Elasticities Positively Correlated}

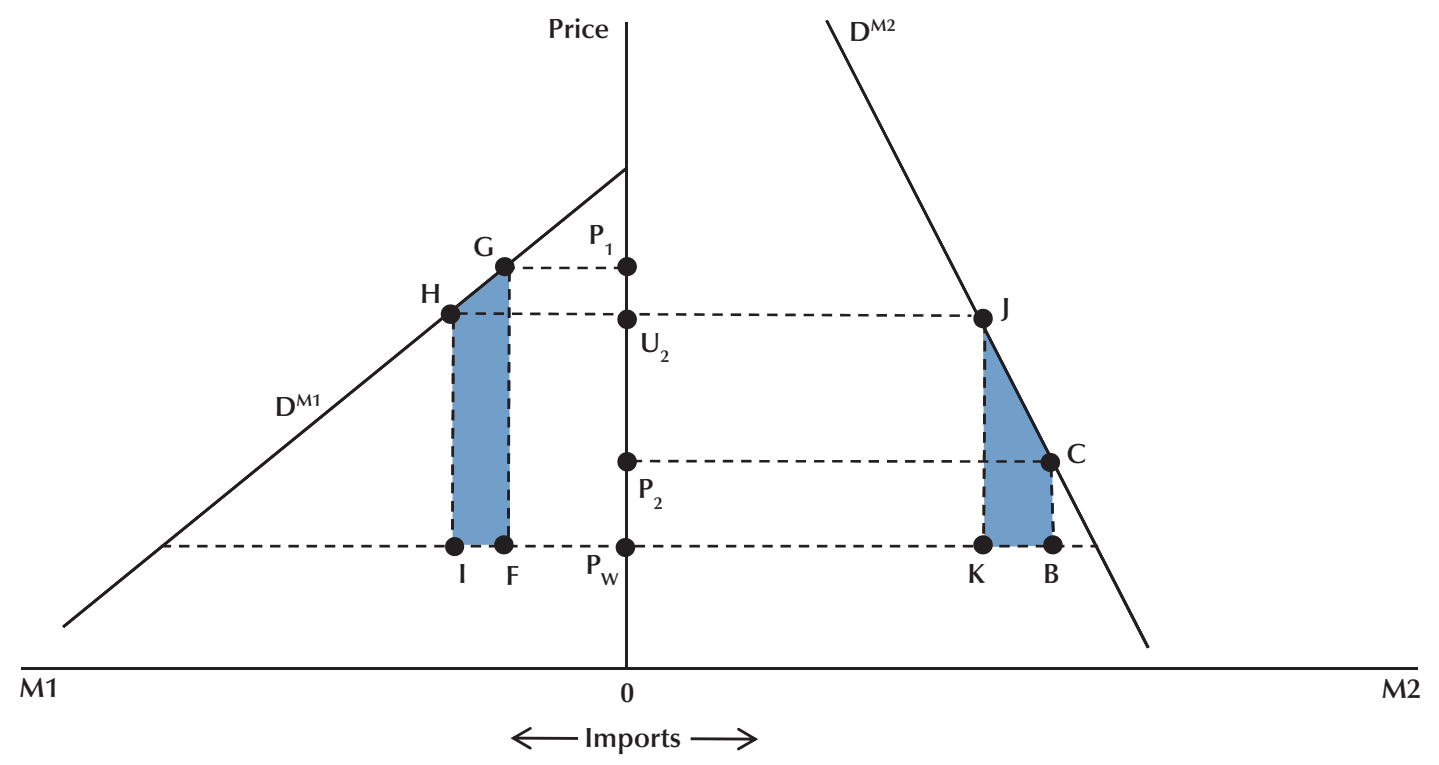

this requirement. When the specific tariff on M1 decreases from $\mathrm{P}_{1}-\mathrm{P}_{\mathrm{W}}$ to $\mathrm{U}_{2}-\mathrm{P}_{\mathrm{W}}$, the increase in welfare (due to the lower price and increased imports) is represented by the area FGHI. At the same time, when the specific tariff on M2 increases from $\mathrm{P}_{2}-\mathrm{P}_{\mathrm{W}}$ to $\mathrm{U}_{2}-\mathrm{P}_{\mathrm{W}}$, the decrease in welfare (due to the higher price and reduced imports) is represented by the area BCJK. Thus, the specific tariff, $\mathrm{U}_{2}-\mathrm{P}_{\mathrm{W}}$, is chosen so that the area FGHI equals the area BCJK. The trade restrictiveness index is simply $\left(\mathrm{U}_{2}-\mathrm{P}_{\mathrm{W}}\right) / \mathrm{P}_{\mathrm{W}}$. Note that, consistent with our previous discussion, the trade restrictiveness index is larger in Figure 5 than in Figure 4.

\section{MOVING FROM THEORY TO REALITY}

So far, the focus here has been on how to aggregate tariff restrictions across different markets. In the graphical analysis, the number of different markets was restricted to two. In reality, the number of different markets is much larger. Kee, Nicita, and Olarreaga (2009) note that it is common to have more than 5,000 tariff lines in a tariff schedule. However, aggregating across different markets is not the only aggregation challenge. An even larger challenge arises because tariffs are not the only form of trade restriction. One must also aggregate different forms of trade policies. In addition to tariff restrictions, trade is also restricted by a variety of other policies, such as quotas, antidumping duties, and technical/safety regulations. ${ }^{12}$ As tariffs were negotiated downward during the second half of the twentieth century, non-tariff barriers tended to rise in importance. To allow these barriers to be compared with tariffs, a common approach is to construct ad valorem tariff equivalents of non-tariff barriers. ${ }^{13}$

12 As noted by Lloyd, Croser, and Anderson (2009), as well as by many others, world agricultural markets are subject to numerous non-tariff policies that distort trade.

${ }^{13}$ For example, a non-tariff barrier could take the form of limiting the quantity of imports. Such a quantity restriction likely causes the price in the importing country to increase from the world price. In this case, the ad valorem tariff equivalent is the difference between the domestic and world prices relative to the world price. 
Such ad valorem tariff equivalents are an essential component in allowing Kee, Nicita, and Olarreaga (2009) to generate estimates of trade restrictiveness indices. ${ }^{14}$ Using a large, multicountry data set on tariffs and non-tariff barriers, they generate estimates using a partial equilibrium approach analogous to the graphical analysis in the previous figures. The focus here will be on the resulting formula for calculating the trade restrictiveness indices rather than on the underlying details of the estimation. ${ }^{15}$

\section{The Uniform Tariff Associated with Unchanged Well-Being}

This index, which we identify as TRI, attempts to answer a basic question: What is the uniform tariff that, if applied to imports in place of the current levels of restriction, would allow home welfare to remain at its current level? As derived by Kee, Nicita, and Olarreaga (2009), the formula for this partial equilibrium trade restrictiveness index that answers this question is as follows:

$$
T R I_{c}=\left(\frac{\sum_{n} m_{n, c} \varepsilon_{n, c} T_{n, c}^{2}}{\sum_{n} m_{n, c} \varepsilon_{n, c}}\right)^{1 / 2} .
$$

That is, for a country, $c$, importing goods designated by $n=1 \ldots N$, the trade restrictiveness index is the square root of the weighted sum of squared protection levels $\left(T_{n, c}^{2}\right)$, where the weights are given by the elasticity of import demand $\left(\varepsilon_{n, c}\right)$ and imports $\left(m_{n, c}\right) .{ }^{16}$

So far in this paper, the focus has been on trade distortions a country imposes that relate directly to its economic well-being. Such a focus allows one to identify the uniform tariff that, if applied to imports in place of the current structure of protection, leaves the home country's well-

\footnotetext{
14 A similar comment applies to recent work by Manole and Spatareanu (2010) and by Lloyd, Croser, and Anderson (2009). The former authors generate yearly trade restrictiveness indices, taking account of all import tariffs for 131 countries between 1990 and 2004; the latter authors produce indices between 1955 and 2007 related to the trade and welfare impacts of distortions to agricultural markets.

${ }^{15}$ See Kee, Nicita, and Olarreaga (2009 and forthcoming).

${ }^{16}$ Kee, Nicita, and Olarreaga (2009) note that the formula for this trade restrictiveness index is based on a second-order linear approximation of "Harberger triangles."
}

being at its current level. This information is potentially very useful. There are, however, other trade restrictiveness indices, two of which are discussed below, that provide additional information that would be useful in trade negotiations and in understanding trade flows. ${ }^{17}$

\section{The Uniform Tariff Associated with Unchanged Aggregate Imports}

Policymakers and the general public are more comfortable thinking in concrete terms. Kee, Nicita, and Olarreaga (2009) generate estimates of trade restrictions that do not hinge on the abstract notion of economic well-being but instead focus on a more concrete measure: the level of trade flows. They create an overall trade restrictiveness index (OTRI) to determine the uniform tariff that, if imposed on imports in place of the existing structure of protection, would leave aggregate imports at their current level. ${ }^{18}$ The formula for their index is as follows:

$$
\operatorname{OTRI}_{c}=\frac{\sum_{n} m_{n, c} \varepsilon_{n, c} T_{n, c}}{\sum_{n} m_{n, c} \varepsilon_{n, c}} .
$$

In this case, the trade restrictiveness index is the weighted sum of protection levels $\left(T_{n, c}\right)$, where the weights are the elasticity of import demand $\left(\varepsilon_{n, c}\right)$ and imports $\left(m_{n, c}\right) \cdot{ }^{19}$ Note that unlike TRI, the variance of protection does not affect this trade restrictiveness index. Moreover, note that this index cannot exceed TRI. ${ }^{20}$

\footnotetext{
${ }^{17}$ See Bach and Martin (2001) and Manole (2004) for a discussion of additional indices.

${ }^{18}$ Lloyd, Croser, and Anderson (2009) make a distinction between a welfare reduction index, which is identified as a specific trade restrictiveness index (TRI) in this paper, and trade reduction indices, which are exemplified by the overall trade restrictiveness index (OTRI) and the market access overall trade restrictiveness index (MA-OTRI).

${ }^{19}$ This index is Anderson and Neary's (2003) "mercantilist trade restrictiveness index."

20 The economic intuition for this result is straightforward. The change from a differentiated to a uniform tariff structure is welfareimproving because such a change eliminates the distortions stemming from the relative price changes caused by a differentiated tariff structure. Because the calculation of OTRI does not preclude economic well-being (i.e., real income) from increasing, the rate associated with TRI must be higher than (or at least as large as) OTRI so that economic well-being is held constant.
} 


\section{The Uniform Tariff Associated with Unchanged Aggregate Exports}

Another potentially useful trade restrictiveness index is based on the following question: What is the uniform tariff that, if imposed by all trading partners on exports of country $c$ in place of their current structure of protection, would leave exports of country $c$ at their current level? This market access overall trade restrictiveness index (MA-OTRI) is the mirror image from the exporter's perspective of OTRI. The formula for MA-OTRI is as follows:

$$
\text { MA-OTRI }=\frac{\sum_{p} \sum_{n} m_{n, c, p} \varepsilon_{n, p} T_{n, c, p}}{\sum_{p} \sum_{n} m_{n, c, p} \varepsilon_{n, p}} .
$$

The subscript $p$ identifies the trading partners of country $c$. That is, this index is the weighted sum of protection levels in other countries $\left(T_{n, c, p}\right)$, where the weights are the elasticities of demand in other countries $\left(\varepsilon_{n, p}\right)$ and their imports from $c\left(m_{n, c, p}\right)$.

\section{Results and Insights}

As mentioned previously, estimates of trade restrictiveness indices have been produced by Kee, Nicita, and Olarreaga (2009) and by Manole and Spatareanu (2010). These indices, which are constructed using many goods for many countries, require information on the protection levels associated with tariffs and non-tariff barriers, the elasticity of import demand, and the level of imports. ${ }^{21}$ Acquiring and, in many cases, generating estimates of the required information is a major job. Moreover, because all this information may change over time, the estimates of these indices are also likely to change over time.

Using a partial equilibrium approach, Kee, Nicita, and Olarreaga (2009) produce estimates for 78 countries of three trade restrictiveness

\footnotetext{
${ }^{21}$ The estimation of these indices requires the authors to deal with numerous challenging data and econometric issues, most of which are beyond the scope of this paper. Assumptions, which can be questioned, must be made. For example, Kee, Nicita, and Olarreaga (2009) assume that an individual country, even a large trader such as the United States, does not affect world prices. Such an assumption has empirical support. For example, Magee and Magee (2008) found that the United States had little power to affect world prices through its trade policies.
}

indices-TRI, OTRI, and MA-OTRI-for two cases, one of which is focused solely on tariffs and one of which combines tariffs and non-tariff barriers. The estimates are based on data for the early 2000s. Table 1 presents their estimates for the uniform tariff based on the combined effects of tariffs and non-tariff barriers. Using a general equilibrium approach, Manole and Spatareanu (2010) generate annual estimates of TRI based solely on tariffs for 131 countries for as many years as the data allowed between 1990 and 2004. ${ }^{22}$ The estimates in both papers provide a number of insights about trade restrictiveness and allow for some interesting analyses. Some of these results and insights are highlighted below.

Let's start with the indices generated by Kee, Nicita, and Olarreaga (2009). The simple average across countries of trade restrictiveness for specific indices that combine tariff and non-tariff barriers is as follows: OTRI, 0.182; MA-OTRI, 0.161 ; and TRI, 0.332 . The OTRI estimates range from 0.017 in Hong Kong to 0.533 in Tanzania. The MA-OTRI estimates range from 0.002 in Algeria to 0.657 in Mauritius. The TRI estimates range from 0.087 in both Costa Rica and Uganda to 0.671 in Tanzania. The trade restrictiveness imposed and faced by the United States is slightly below average: OTRI, 0.104; MA-OTRI, 0.130; and TRI, 0.294. In ranking the 78 countries with 1 being the least restrictive and 78 being the most restrictive, the ranking of the United States is as follows: OTRI, 21; MA-OTRI, 38; and TRI, 35.

Non-tariff barriers constitute a substantial portion of trade restrictiveness for many countries. For example, the average of trade restrictiveness using only tariffs relative to using tariffs and nontariff barriers is 0.555 for OTRI, 0.305 for MA-OTRI, and 0.497 for TRI. In other words, on average across countries, tariffs as a share of the total effect of tariffs and non-tariff barriers account for 56 percent of OTRI, 31 percent of MA-OTRI, and 50 percent of TRI.

For a number of countries, non-tariff barriers provide more trade restrictiveness than tariffs. For example, the TRI for the United States solely

\footnotetext{
${ }^{22}$ One reason for the difference in country coverage is that Kee, Nicita, and Olarreaga (2009) combine members of the European Union into one "country," while Manole and Spatareanu (2010) do not.
} 
Table 1

Trade Restrictiveness Indices

\begin{tabular}{|c|c|c|c|c|c|c|}
\hline Country & OTRI & Rank & MA-OTRI & Rank & TRI & Rank \\
\hline Albania & 0.124 & 26 & 0.340 & $69(\mathrm{~T})$ & 0.150 & 8 \\
\hline Algeria & 0.392 & 73 & 0.002 & 1 & 0.557 & 71 \\
\hline Argentina & 0.181 & 50 & 0.275 & 64 & 0.279 & 33 \\
\hline Australia & 0.119 & $23(\mathrm{~T})$ & 0.147 & 46 & 0.250 & 26 \\
\hline Bangladesh & 0.255 & $62(\mathrm{~T})$ & 0.346 & 71 & 0.399 & 56 \\
\hline Belarus & 0.168 & 44 & 0.101 & 32 & 0.312 & 41 \\
\hline Bolivia & 0.148 & 35 & 0.122 & 37 & 0.272 & 32 \\
\hline Brazil & 0.270 & 64 & 0.149 & 47 & 0.497 & 68 \\
\hline Brunei & 0.185 & 51 & 0.056 & 16 & 0.596 & 73 \\
\hline Burkina Faso & 0.158 & $40(\mathrm{~T})$ & 0.121 & 36 & 0.268 & 31 \\
\hline Cameroon & 0.164 & 43 & 0.138 & 45 & 0.224 & 20 \\
\hline Canada & 0.063 & 7 & 0.072 & 24 & 0.191 & $12(\mathrm{~T})$ \\
\hline Chile & 0.110 & 22 & 0.158 & 49 & 0.202 & $14(\mathrm{~T})$ \\
\hline China & 0.204 & 54 & 0.066 & $19(\mathrm{~T})$ & 0.343 & 45 \\
\hline Colombia & 0.249 & 61 & 0.132 & $39(\mathrm{~T})$ & 0.456 & 61 \\
\hline Costa Rica & 0.050 & 5 & 0.202 & 53 & 0.087 & $1(\mathrm{~T})$ \\
\hline Cote d'Ivoire & 0.315 & $67(\mathrm{~T})$ & 0.263 & 62 & 0.495 & 67 \\
\hline Czech Republic & 0.049 & 4 & 0.027 & 10 & 0.094 & 3 \\
\hline Egypt & 0.411 & 74 & 0.088 & 30 & 0.586 & 72 \\
\hline El Salvador & 0.132 & 28 & 0.454 & 76 & 0.257 & 28 \\
\hline Estonia & 0.024 & 2 & 0.064 & 18 & 0.132 & 6 \\
\hline Ethiopia & 0.151 & 36 & 0.490 & 77 & 0.222 & 19 \\
\hline European Union & 0.079 & 13 & 0.086 & 29 & 0.406 & 60 \\
\hline Gabon & 0.155 & 38 & 0.003 & 2 & 0.178 & 11 \\
\hline Ghana & 0.178 & $46(\mathrm{~T})$ & 0.321 & 68 & 0.296 & 36 \\
\hline Guatemala & 0.180 & 49 & 0.349 & 72 & 0.356 & $47(\mathrm{~T})$ \\
\hline Honduras & 0.085 & 18 & 0.379 & 75 & 0.161 & 9 \\
\hline Hong Kong & 0.017 & 1 & 0.174 & 51 & 0.122 & 5 \\
\hline Hungary & 0.119 & $23(\mathrm{~T})$ & 0.055 & 15 & 0.259 & $29(\mathrm{~T})$ \\
\hline Iceland & 0.064 & 8 & 0.226 & 57 & 0.234 & 21 \\
\hline India & 0.327 & 70 & 0.162 & 50 & 0.469 & 62 \\
\hline Indonesia & 0.080 & 14 & 0.136 & 43 & 0.202 & $14(\mathrm{~T})$ \\
\hline Japan & 0.319 & 69 & 0.076 & $26(\mathrm{~T})$ & 0.660 & 77 \\
\hline Jordan & 0.255 & $62(\mathrm{~T})$ & 0.209 & 55 & 0.405 & 59 \\
\hline Kazakhstan & 0.162 & 42 & 0.036 & 11 & 0.364 & 50 \\
\hline Kenya & 0.131 & 27 & 0.340 & $69(\mathrm{~T})$ & 0.213 & $16(\mathrm{~T})$ \\
\hline Latvia & 0.139 & $32(\mathrm{~T})$ & 0.046 & 14 & 0.337 & 44 \\
\hline Lebanon & 0.202 & 53 & 0.137 & 44 & 0.402 & $57(\mathrm{~T})$ \\
\hline Lithuania & 0.057 & 6 & 0.116 & 34 & 0.191 & $12(\mathrm{~T})$ \\
\hline Madagascar & 0.043 & 3 & 0.277 & $65(\mathrm{~T})$ & 0.109 & 4 \\
\hline Malawi & 0.156 & 39 & 0.197 & 52 & 0.254 & 27 \\
\hline Malaysia & 0.242 & $59(\mathrm{~T})$ & 0.067 & $21(\mathrm{~T})$ & 0.476 & 63 \\
\hline
\end{tabular}




\begin{tabular}{|c|c|c|c|c|c|c|}
\hline \multicolumn{7}{|c|}{ Trade Restrictiveness Indices } \\
\hline Country & OTRI & Rank & MA-OTRI & Rank & TRI & Rank \\
\hline Mali & 0.135 & 31 & 0.015 & 6 & 0.213 & $16(\mathrm{~T})$ \\
\hline Mauritius & 0.217 & 57 & 0.657 & 78 & 0.402 & $57(\mathrm{~T})$ \\
\hline Mexico & 0.315 & $67(\mathrm{~T})$ & 0.067 & $21(\mathrm{~T})$ & 0.493 & 66 \\
\hline Moldova & 0.074 & 11 & 0.203 & 54 & 0.243 & 24 \\
\hline Morocco & 0.484 & 77 & 0.223 & 56 & 0.627 & $75(\mathrm{~T})$ \\
\hline New Zealand & 0.133 & $29(\mathrm{~T})$ & 0.355 & 73 & 0.305 & 38 \\
\hline Nicaragua & 0.141 & 34 & 0.243 & 58 & 0.307 & 39 \\
\hline Nigeria & 0.424 & 75 & 0.012 & 5 & 0.617 & 74 \\
\hline Norway & 0.083 & $16(\mathrm{~T})$ & 0.022 & $8(\mathrm{~T})$ & 0.345 & 46 \\
\hline Oman & 0.178 & $46(\mathrm{~T})$ & 0.010 & 4 & 0.365 & $51(\mathrm{~T})$ \\
\hline Papua New Guinea & 0.101 & 19 & 0.104 & 33 & 0.308 & 40 \\
\hline Paraguay & 0.207 & 55 & 0.135 & 42 & 0.356 & $47(\mathrm{~T})$ \\
\hline Peru & 0.229 & 58 & 0.133 & 41 & 0.397 & 55 \\
\hline Philippines & 0.170 & 45 & 0.076 & $26(\mathrm{~T})$ & 0.361 & 49 \\
\hline Poland & 0.152 & 37 & 0.062 & 17 & 0.281 & 34 \\
\hline Romania & 0.179 & 48 & 0.154 & 48 & 0.300 & 37 \\
\hline Russia & 0.288 & 66 & 0.022 & $8(\mathrm{~T})$ & 0.480 & 64 \\
\hline Rwanda & 0.133 & $29(\mathrm{~T})$ & 0.083 & 28 & 0.242 & 23 \\
\hline Saudi Arabia & 0.158 & $40(\mathrm{~T})$ & 0.016 & 7 & 0.371 & 53 \\
\hline Senegal & 0.375 & 72 & 0.246 & 59 & 0.537 & 70 \\
\hline Slovenia & 0.194 & 52 & 0.038 & 12 & 0.323 & 43 \\
\hline South Africa & 0.081 & 15 & 0.074 & 25 & 0.162 & 10 \\
\hline Sri Lanka & 0.076 & 12 & 0.277 & $65(\mathrm{~T})$ & 0.142 & 7 \\
\hline Sudan & 0.458 & 76 & 0.093 & 31 & 0.627 & $75(\mathrm{~T})$ \\
\hline Switzerland & 0.067 & 9 & 0.066 & $19(\mathrm{~T})$ & 0.247 & 25 \\
\hline Tanzania & 0.533 & 78 & 0.251 & 60 & 0.671 & 78 \\
\hline Thailand & 0.139 & $32(\mathrm{~T})$ & 0.132 & $39(\mathrm{~T})$ & 0.259 & $29(\mathrm{~T})$ \\
\hline Trinidad \& Tobago & 0.083 & $16(\mathrm{~T})$ & 0.039 & 13 & 0.321 & 42 \\
\hline Tunisia & 0.368 & 71 & 0.264 & 63 & 0.527 & 69 \\
\hline Turkey & 0.102 & 20 & 0.117 & 35 & 0.235 & 22 \\
\hline Uganda & 0.068 & 10 & 0.377 & 74 & 0.087 & $1(\mathrm{~T})$ \\
\hline Ukraine & 0.285 & 65 & 0.069 & 23 & 0.489 & 65 \\
\hline United States & 0.104 & 21 & 0.130 & 38 & 0.294 & 35 \\
\hline Uruguay & 0.211 & 56 & 0.300 & 67 & 0.365 & $51(\mathrm{~T})$ \\
\hline Venezuela & 0.242 & $59(\mathrm{~T})$ & 0.009 & 3 & 0.393 & 54 \\
\hline Zambia & 0.121 & 25 & 0.252 & 61 & 0.219 & 18 \\
\hline Mean & 0.182 & & 0.161 & & 0.332 & \\
\hline Range & $0.017-0.533$ & & $0.002-0.657$ & & $0.087-0.671$ & \\
\hline
\end{tabular}

NOTE: This table is based on Table 4 in Kee, Nicita, and Olarreaga (2009). The measure includes the impact of tariffs and non-tariff barriers. The ranks are ordered from least restrictive (1) to most restrictive (78); (T) indicates a tie in rank. 
based on tariffs is 0.051 and based on tariffs and non-tariff barriers is 0.294; thus, tariffs account for less than 20 percent of the overall trade restrictiveness. Tariffs also account for less than 20 percent of the overall trade restrictiveness for the European Union.

Looking across all countries, the ratios of tariff to non-tariff barriers for trade restrictiveness range from zero to one. For example, the ratio pertaining to overall trade restrictiveness for Hong Kong, which has no tariffs, is zero, while the ratio for Gabon, which uses only tariffs, is one. Obviously, for many countries, a focus exclusively on tariffs produces a misleading view of trade restrictiveness. ${ }^{23}$

The results in Table 1 also show that the TRI, which is based on economic well-being, is larger than the OTRI, which is based on trade volume. For many countries, especially developed countries, the TRI is more than double the OTRI. For example, the TRI for the United States (0.294) is nearly three times its OTRI (0.104). For the European Union, its TRI (0.406) is more than five times its OTRI (0.079).

By using these indices in some straightforward calculations, Kee, Nicita, and Olarreaga (2009) generate some additional observations that can provide the foundation for additional studies. They find a negative association between OTRI and GDP per capita (technically the natural logarithm of GDP per capita), which suggests that rich countries tend to impose lower trade barriers on imports. They also find a negative association between MA-OTRI and GDP per capita, which suggests that rich countries face lower trade restrictions on their exports than do poor countries. The preceding findings may be explained by reciprocity in trade agreements in that countries with high import trade barriers likely face high barriers on their exports.

Finally, Kee, Nicita, and Olarreaga (2009) find no clear pattern between TRI and GDP per capita. They suggest that the variance of the pro-

\footnotetext{
23 Although these specific examples use estimates of TRI, the generalizations in the paragraph pertain to the other measures of trade restrictiveness as well. For example, Kee, Nicita, and Olarreaga (2009) note that in 34 of the 78 countries the impact of non-tariff barriers on OTRI is larger than the impact of tariffs. Thus, a focus on tariffs alone can be misleading.
}

tection structure in rich countries tends to offset the lower trade restrictions associated with OTRI and MA-OTRI. Also, structural adjustment programs may reduce the tariff variance and levels in many low-income countries.

However, Manole and Spatareanu (2010) do find a negative relationship between trade restrictiveness and per capita income. They argue that lower protection leads to higher per capita income. Many reasons can be offered for the differing results between Kee, Nicita, and Olarreaga (2009) and Manole and Spatareanu (2010). First, the former study explores only the relationship between trade restrictiveness and GDP per capita, while the latter study controls for the impact of other variables that might affect GDP per capita. Accounting for the impact of other variables could influence the estimated relationship between trade restrictiveness and GDP per capita. Second, the former study uses the level of trade restrictiveness and the natural logarithm of GDP, while the latter study uses the natural logarithms of both variables. Estimations based on different functional forms, semi-log versus log-linear, can lead to differing results. Third, the former's measure of trade restrictiveness uses tariffs and non-tariff barriers, while the latter uses only tariffs. As noted previously, a measure based on tariffs and nontariff barriers might well behave differently from a measure based on only tariffs. Moreover, differences in the data used (e.g., countries in the sample and the years considered) and the estimation of trade restrictiveness likely come into play as well.

To provide additional information on the similarity of the generated indices, I have taken the countries used in both studies and focused on the overall restrictiveness indices that are based on tariffs alone. For the 74 common countries, the average trade restrictiveness index generated by Manole and Spatareanu (2010) was 0.169, with a range of 0 to 0.45 , while the average trade restrictiveness index generated by Kee, Nicita, and Olarreaga (2009) was 0.153 , with a range of 0.046 to $0.418 .^{24}$ The correlation coefficient between

\footnotetext{
${ }^{24}$ Because Manole and Spatareanu (2010) calculate a time series for each country, while Kee, Nicita, and Olarreaga (2009) generate one estimate for each country, additional calculations underlie this simple calculation. Details are available upon request.
} 
the two measures was 0.56. Thus, these two indices, while similar, are far from interchangeable and caution should be taken in using and interpreting empirical results using these indices.

\section{CONCLUSION}

Constructing a single number that accurately summarizes the effects of various international trade distortions is a major challenge. Trade restrictiveness indices represent a significant improvement over commonly used measures of the stance of trade policy, such as trade-weighted average tariffs, coefficients of variation of tariffs, and non-tariff barrier coverage ratios. Trade restrictiveness indices are grounded in theory and can handle different forms of protection simultaneously.

This paper has highlighted the existence of three trade restrictiveness indices. The existence of multiple indicators follows from the issue under consideration. One measure cannot simultaneously capture the trade distortions that a country imposes on itself and the trade distortions that a country imposes on its trading partners. In many cases, the preferred measure is one that relates trade restrictions to domestic welfare. This measure, identified as TRI (i.e., trade restrictiveness index), converts a country's current structure of protection into a uniform tariff rate so that the country's economic well-being is unchanged. Meanwhile, two other measures discussed here, focused on trade flows and market access, gener- ate measures of uniform tariff rates that maintain the level of trade. For example, the measure identified as OTRI (i.e., overall trade restrictiveness index) converts a country's current structure of protection into a uniform tariff rate so that the country's level of aggregate imports is unchanged, while the measure identified as MA-OTRI (i.e., market access overall trade restrictiveness index) converts the current structures of protection for all the trading partners of a country into a uniform tariff rate so the country's level of aggregate exports is unchanged.

Recent progress in estimating trade restrictiveness indices suggests that such indices will become increasingly prominent in informing those involved in trade negotiations and in research. For example, the indices provide basic information for trade negotiations. They can be used in growth studies to assess the impact of trade policies on income. They can also be used in research aimed at explaining trade costs. These indices also provide various insights about the openness of an economy and how openness has changed over time. As illustrated by Kee, Nicita, and Olarreaga (2009), the indices allow for comparisons of developed economies with developing economies. They found that poor countries have more restrictive trade policies than rich countries, but also face relatively more restrictive trade policies. Finally, the indices can be used for specific issues, such as assessing a country's fulfillment of its World Trade Organization commitment. 


\section{Coughlin}

\section{REFERENCES}

Anderson, James E. “Trade Restrictiveness Benchmarks.” Economic Journal, July 1998, 108(449), pp. 1111-25.

Anderson, James E. and Neary, J. Peter. “Trade Reforms with Quotas, Partial Rent Retention and Tariffs.” Econometrica, January 1992, 60(1), pp. 57-76.

Anderson, James E. and Neary, J. Peter. "Measuring the Restrictiveness of Trade Policy." World Bank Economic Review, May 1994, 8(2), pp. 151-69.

Anderson, James E. and Neary, J. Peter. “A New Approach to Evaluating Trade Policy.” Review of Economic Studies, January 1996, 63(1), pp. 107-25.

Anderson, James E. and Neary, J. Peter. “The Mercantilist Index of Trade Policy.” International Economic Review, May 2003, 44(2), pp. 627-49.

Anderson, James E. and Neary, J. Peter. Measuring the Restrictiveness of Trade Policy. Cambridge, MA: MIT Press, 2005.

Anderson, James E. and Neary, J. Peter. "Welfare versus Market Access: The Implications of Tariff Structure for Tariff Reform.” Journal of International Economics, March 2007, 71(2), pp. 187-205.

Bach, Christian F. and Martin, Will. "Would the Right Tariff Aggregator for Policy Analysis Please Stand Up?” Journal of Policy Modeling, August 2001, 23(6), pp. 621-35.

Kee, Hiau Looi; Nicita, Alessandro and Olarreaga, Marcelo. "Estimating Trade Restrictiveness Indices.” Economic Journal, January 2009, 119(534), pp. 172-99.

Kee, Hiau Looi; Nicita, Alessandro and Olarreaga, Marcelo. "Import Demand Elasticities and Trade Distortions.” Review of Economics and Statistics, forthcoming.

Lloyd, Peter J.; Croser, Johanna L. and Anderson, Kym. “Global Distortions to Agricultural Markets: New Indicators of Trade and Welfare Impacts, 1955 to 2007.” World Bank Policy Research Working Paper No. 4865, March 2009.

Magee, Christopher S.P. and Magee, Stephen P. “The United States Is a Small Country in World Trade.” Review of International Economics, November 2008, 16(5), pp. 990-1004.

Manole, Vlad. "Keeping the Devil in the Details: Feasible Approaches to Aggregating Trade Distortions,” in Essays on Migration and Diversity, Tariff Aggregators and the Productivity of Banking Systems. Dissertation, Washington University, December 2004.

Manole, Vlad and Spatareanu, Mariana. "Trade Openness and Income-A Re-examination." Economics Letters, January 2010, 106(1), pp. 1-3. 